\title{
PENTINGNYA PERAN BAHASA DALAM PENDIDIKAN USIA DINI (PAUD)
}

\author{
Muflihah
}

Dosen Jurusan Tarbiyah STAIN Kudus

\begin{abstract}
Language is the tool of human interaction to convey a message or idea in fikiranya. It is an extraordinary thing if they were involved in early childhood education teaching materials capable of delivering them well. The students of this age are vulnerable times for them. If they are too restrained, it will hinder their psychological development, and vice versa if they are also not be allowed, it will stabilize their development. Therefore at this time they still play, seek attention, and look for praise. Then an educator should be able to convey recording a language pack.
\end{abstract}

Keywords: Early Childhood Education, language role

\section{PENDAHULUAN}

Bahasa adalah alat interaksi manusia untuk menyampaikan pesan atau ide yang ada dalam fikiranya. Adalah suatu hal yang luar biasa apabila mereka yang berkecimpung dalam dunia pendidikan usia dini mampu menyampaikan materi ajar mereka dengan baik. Sebagaimana diketahui bersama bahwa anak didik diusia ini adalah masa-masa yang rawan bagi mereka. Apabila terlalu dikekang akan menghambat perkembangan psikis mereka, begitupun sebaliknya apabila terlalu dibiarkan akan juga tidak akan menstabilkan perkembangannya. Oleh karena anak didiknya masih masamasa mereka bermain, mencari perhatian, mencari pujian, maka seorang tenaga pendidik harus bisa mengemas bahasa yang merekan sampaikan.

Berdasar pada paparan di atas penulis hendak memaparkan bagaimana bahasa itu, apa fungsinya dan bagaimana tahapan berbahasa. Hal ini bertujuan untuk memberi tambahan wacana akan pentingnya sebuah bahasa. 


\section{A. Bahasa dan Berbahasa}

Bahasa dan berbahasa adalah dua kata yang berbeda. Bahasa adalah alat verbal yang digunakan untuk berkomunikasi, sedangkan berbahasa adalah proses penyampaian informasi dalam berkomunikasi itu.

\section{B. Hakikat Bahasa}

Para pakar linguistik deskriftip biasanya mendefinisikan bahasa sebagai "satu sistem lambang bunyi yang bersifat arbiter" yang kemudian lazim ditambah dengan "yang digunakan oleh sekelompok anggota mansyarakat untuk berinteraksi mengidentifikasikan diri". Bagian utama dari definisi di atas menyatakan hakikat bahasa itu, dan bagian tambahan menyatakan apa fungsi bahasa itu (Abdul Chaer, 2002:30-31).

\section{Karakteristik Bahasa}

a) Oral

Bloomfiled (1979) dalam Suparno (1995) mengemukakan bahwa bahasa pada hakikatnya adalah lisan (Oral). Karakter ini terkihat pada kenyataan bahwa semua itu manusia berbahasa secara lisan, tetapi sebagian dari mereka tidak bisa menulis atau tidak mengenal lambing tulis. Dengan ungkapan yang mudah, dikatakan bahwa kadang-kadang ditemukan adanya warga masyarakat bahasa bahasa yang buta huruf.

b) Sistematis, sistematis, komplit

Sistematis, maksudnya setiap bahasa mempunyai aturanaturan khas. Bahasa itu bekerja sesuai aturannya masing-masing. Sebagai contoh dalam BA misalnya, bunyi ن[t] dzalqy latsawiy asnaniy muraqqaq 'apiko dentalveolar non-emfatik' tidak pernah mengikuti

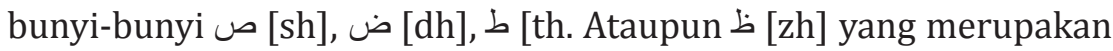
bunyi dzalqy latsawiy asnaniy mufkhkam 'apiko dentalveolar emfatik'. Dalam BA tidak ditemukan kata اصنتر [ishtabara], مضتر [mudhtarr], dan مصتفى [musththafa]. Bunyi ن [t] yang non-emfatik tersebut dijadikan emfatik sesuai dengan bunyi yang mendahului sehingga yang terjadi adalah kata اصطبر [ishthabar], مضطر [mudhtharr], dan [mushthafa].

c) Arbitrar dan simbolis

Albitrer atau semena-mena, artinya tidak terdapat hubungan 
yang rasional antara lambang verbal dan acuannya. Sebagai contoh, benda cair bening yang biasa diminum dalam BA disebut دماء dalam BI disebut air, dan dalam bahasa Inggris disebut water. Kata-kata dalam setiap bahasa merupakan lambing-lambang benda nyata, abstrak, gagasan, dan sebagainya. Dengan sifat simbolis yang dimiliki bahasa, manusia dapat mengabstraksikan berbgai pengalaman dan pikiran atau berbicara tentang berbagai hal termasuk hal-hal yang belum pernah kita alami sekalipun.

d) Konvensional

Konfensional, maksudnya hubungan antara lambing dan acuan beserta aturan yang ada dalam bahasa merupakan kesepakatan masyarakat pengguna bahasa. Kesepakatan yang dimaksudkan bukanlah kesepakatan formal sebagai hasil dari suatu konferensi atau mukhtamar yang melibatkan semua atau sekian banyak anggota masyarakat. Kesepakatan yang dimaksudkan pada dasarnya merupakan kebiasaan yang berlangsung turun temurun sejak nenek moyang. Meskipun demokian, kesepakatan tersebut bersifat sangat mengikat dan harus diikuti oleh semua pemakai bahasa. Jika seseorang tidak mematuhi dan menyimpang dari kesepakatan bersama tersebut maka bahasa yang diturunkannya tidak akan dipahami atau paling tidak akan dipahami secara menyimpang oleh orang lain dalam masyarakat yang sama.

e) Unik dan universal

Unik, artinya setiap bahasa memeiliki ciri khas yang berbeda dari bahasa yang lain. Kekhasan itu terdapat pada berbagai subsistem bahasa. Dalam sub-sistem bunyi, BA banyak memiliki bunyi-

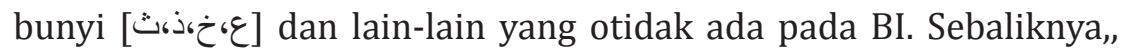
dalam BI terdapat sejumlah bunyi yang tiidak terdapat pada BA, mislanya bunyi $[p, c, e, g]$.

f) Beragam

Beragam, artinya bahasa itu mewujud dalam maujud yang bervariasi. Keberagaman bahasa itu bisa berupa dialek, sosiolek, bahkan juga idiolek. Maujud bahasa yang dimaksud dialek merupakan kategori ragam bahasa berdasarkan geografi. Ragam bahasa berdasarkan tingkat sosial pemakai disebut sosialek. Adapun ideolek merupakan maujud bahasa dari masing-masing individu pada suatu kelompok masyarakat. Kridalaksana (dalam Suparno, 1995) mengemukakan bahwa setiap manusia mempunyai kepribadian 335 
yang berbeda-beda. Perbedaan kepribadian itu menampak pada perilaku bahasanya.

g) Berkembang

Bahasa yang masih digunakan oleh manusia untuk berkomonikasi mempunyai sifat selalu berkembang adalah khazanah kata. Sifat berkembang inipun ada pada BA. Sebagai contoh dalam bahasa Arab terdapat sejumlah kata yang merupakan hasil penyerapan dari bahasa lain, misalnya tilfiziyun, tilfun,dan radiyu. Kata-kata al-hasib al-aliy dan barid ilikruniy misalnya juga merupakan dua kata BA yang baru muncul seiring dengan era teknologi computer.

h) Produktif-Kreatif

Produktif dan kreatif maksudnya produksi suatu bahasa itu sangat melimpah. Dengan fasilitas yang terbatas dapat dihasilkan kalimat yang tidak berbatas. Dengan jumlah bunyi yang sangat kecil dapat dihasilkan ribuan jumlah kata. Demikian halnya dari jumlah jenis kalimat yang terbatas yang dihasilkan kalimat yang tidak terbatas pula.

i) Fenomena social

Bahasa pada dasarnya merupakan fenomena social. Artinya bahasa itu merupakan konvensi suatu masyarakat pemilik atau pengguna bahasa itu. seseorang menggunakan suatu bahasa sesuai dengan norma-norma yang disepakati atau dotetapkan untuk bahasa itu.

j) Insane

Insane bahasa bersifat insani maksudnya bahasa itu merupakan produk manusia. Memang hanya manusialah yang mempunyai kemampuan untuk berbahasa. Dengan kemampuan berbahasa yang dimilikinya, manusia dan berkembang sedemikian rupa melebihi makhluk-makhluk lainnya.

\section{Fungsi Bahasa}

Bahasa merupakan alat komonikasi. Untuk keperluan apapun dan dalam kegiatan apapun bahasa yang digunakan oleh seseorang atau suatu masyarakat, maka untuk keperluan tersebut dan dalam kegiatan tersebut bahasa digunakan sebagai alat komonikasi. Fungsi bahasa sebagai alat komunikasi tersebut merupakan fungsi umum bahasa. 
Hasanaini (1984) mengemukakan adanya dua fungsi bahasa yaitu (a) sebagai alat komonikasi dan (b) sebagai alat untuk menyatakan kebudayaan dan peradaban. Dengan munculnya agama Islam misalnya, BA mulai mengungkapkan atau menyatakan kebudayaan dan peradaban Islam. Mulai masa itu, dalam BA muncul istilah-istilah baru sebagai cerminan dari kebudayaan Islam, misalanya kata zakat, shawm, raka'at, jihad, dan sebagainya.

Selain fungsi umum tersebut, bahasa mempunyai sejumlah fungsi khusus. Halliday (1970) dalam Azies dan Alwasilah (1996) menawarkan penjabaran penggunaan bahasa secara fungsional. Menurutnya ada sejumlah tujuh fungsi khusus bahasa yang tampak pada penggunaan bahasa sebagai alat komonikasi

- Fungsi instrumental: menggunakan bahasa untuk memperoleh sesuatu

- Fungsi regulatori: menggunakan bahasa untuk mengontrol perilaku orang lain

- Fungsi personal, yaitu fungsi bahas yang tampak pada penggunaan bahasa untuk mengungkapkan perasaan dan ide

- Fungsi interaksional, fungsi bahasa yang melekat ketika digunakan untuk menciptakan interaksi dengan orang lain.

- Fungsi heoristik: menggunakan bahasa untuk belajar dan menemukan makna.

- Fungsi imajinatif: menggunakan bahasa untuk menciptakan dunia imajinasi.

- Fungsi representasional: menggunakan bahasa intuk menyampaikan informasi

Agak berbeda dengan Halliday, Finochiaro (dalam Suparno, 1995) mengemukakan lima fungsi khusus dalam bahasa.

- Fungsi personal, yaitu fungsi bahasa untuk menyatakan diri

- Funsi interpersonal, merupakan fungsi bahasa untuk menjalin dan membangun hubungan dengan orang lain.

- Fungsi direktif, yaitu fungsi bahasa untuk mengatur orang lain.

- Fungsi refrensial adalah fungsi bahasa untuk menyatakan suatu acuan konkrit ataupun abstrak dengan menggunakan lambang bahasa

- Fungsi imajinatif merupakan fungsi bahasa untuk menciptakan sesuatu dengan berimajinasi. 
Dari penjelasan tentang setiap fungsi yang baru dikemukakan dapat diketahui adanya persamaan antara fungsi yang dikemukakan oleh keduanya. Keduanya menyatakan adanya fungsi personal dan fungsi imajinatif. Selain itu tampak adanya kesepadanan antara fungsi interaksional dan funsi interpersonal, fungsi direktif dan fungsi regulatori, fungsi representasional dan fungsi referensional.

Fungsi-fungsi bahasa tersebut lebih lanjut oleh holliday dikelompokkan menjadi tiga (1) fungsi interpersonal: untuk membentu, mempertahankan, dan memperjelas hubungan diantara anggota masyarakat, (2) fungsi ideasional: untuk menyampaikan infoirmasi diantara anggota masyarakat, dan (3) fungsi tekstual: untuk menyediakan kerangka, pengorganisasian diskursus yang relevan dengan situasi. (Imam Asrori, 2004: 8-18).

\section{Tahapan Prabahasa}

Dalam tahapan prabahasa anak belum berbicara; belum waktunya dibicarakan tentang "alat bicara". Sejak lahir anak mampu untuk benapas dan minum. Kedua perbuatan itu harus dikoordinasi sedemikian rupa hingga dapat dilakukan bersama-sama. Itulah fungsi primer alat bicara yang diberi oleh alam. Koordinasi gerakan bersamaan alat itu merupakan dasar kemampuan bicara anak. Berbicara adalah fungsi sekunder dari organ yang kompleks tersebut, yang diberi oleh alam, tetapi harus diperoleh lewat proses belajar. Proses itu seluruhnya tergantung pada pendengaran: bunyibunyi yang dihasilkan dan di dengar sendiri terus menerus diperbaiki dan disuaikan dengan bunyi-bunyi yang didengar dari lingkungan (umpan balik).

Perkembangan bahasa pada tahap prabahasa ini terjadi dalam beberapa fase. Dalam tahapan prabahasa, anak bersuara. Pertama-tama, ia berusaha dengan jalan menutup celah dalam_larynx sewaktu mengeluarkan nafas; ia menangis. Kemudian, ia menggetarkan celah itu dengan lebih tenang; ini dinamakan dengan vokalisasi. Selanjutnya, ia menggerakkan atau hampir menutup bagian lain dari mulut sewaktu bersuara; fase ini dinamakan fase raban, lalu ia menghasilkan raban dengan bunyi wicara dari bahasa ibunya; ini dinamakan fase penyesuaian. Tahap prabahasa diakhiri jika tahapan kalimat satu kata dimulai. Dalam tahapan ini, di samping raban yang disesuaikan, juka makin sering didengar kata-kata.

Paparan di atas memperlihatkan pengembangan pengeluaran wicara yang pertama itu. perkembangan yang dimaksud mengambil waktu kira-kira 338 satu tahun dan dengan jelas berjalan menurut beberapa fase yang berbeda. 
"fase" ditadak berarti bahwa tahapan sebelumnya berhenti, tetapi bahwa ada cirri baru yang bertambah.

Sebenarnya agak berbahaya untuk memisahkan (menentukan waktu) fase-fase tersebut. Artinya, dikatakan bahwa fase-fase itu berlangsung sekian bulan tepat. Persepatan perkembangan terlalu berbeda dari satu anak ke anak lainnya. Perkembangan yang lebih cepat atau lebih lambat tidak memberi indikasi tentang kecerdasan yang lebih tinggi atau lebih rendah atau tentang keterlambatan yang harus dikhawatirkan.

Anak bekembang sesuai dengan temponya sendiri, yang terutama di tentukan oleh kematangan neurologis. Lingkungan memang dapat mendukung itu secara optimal dan dapat juga mempengaruhinya dengan negative, sehingga lingkungan dapat mempercepat atau memperlambatnya. Namun, juga di bawah kondisi optimal atau perbedaan perorangan yang belum tentu berkolerasi dengan kecerdasan. Kondisi-kondisi yang ekstrim negative dapat menghambat perkembangan atau bahkan dapat mengakibatkan kelainan tetap. Kondisi seperti itu adalah misalnya lesi (cedera) pada otak, ketulian, sakit yang lama, keterlantaran yang sangat. Fase-fase yang akan dibicarakan di sini adalah menagis, vokalisasi, raban, dan penyesuaian.

\section{Menangis}

Tangis pada anak mulanya buakanlah pengungkapan rasa sedih, bahkan juga bukan dari rasa ketidaknyamanan, tetapi merupakan suatu aktivitas fisiologi murni. Baru setelah beberapa waktu, tangis fisiologis berkembang menjadi tanda primitive dan ketidaknyamanan.

Pengetahuan pengalaman pertama dari hubungan antara tangis dan akibatnya, yaitu pertolongan, menjadikan tangis sebagai bentuk pertama dari komunikasi. Komunikasi tersebut tidak sepihak sebab dari pihak ibi (lingkungan) ada suara menenangkan yang menyertai perawatan dan yang menandakan pada bayi bahwa kesedihannya telah dipahami. Biyi mengalami suara ibunya sebagai penghibur dan hal itu adalah komponen penting dalam kontak total dengan ibunya Karen ia tidak hanya mengalami bahwa sebab kesedihannya hilang, tetapi ia juga menjadi dasar akan kontak dengan sesame manusia.

Sesudah tingkat tertentu ducapai, tangis tidak berkembang lagi karena tidak mendapat tanggapan. Manusia dewasa hanya kembali pada tangis dalam situasi ketika ia tidak lagi dapat menguasai dirinya. 


\section{Vokalisasi}

Disamping menangis masih ada macam suara lain yang baru berkembang sesuadah tangis yang digambarkan di atas. Sesudah kurang lebih enam minggu, makin sering terjadi bahwa bunyi tidak menangis, tetapi berbaring dan bernafas dengan tenang, biasanya sesudah tidur dan minum. Pita suara dipertemukan dengan tenang yang mengakibatkan suara panjang, kira-kira seperti [ah] ... [ah] ... suara itu dengan cepat digunakan oleh anak sebagai pengungkapan rasa senang dan nyaman, terutama dalam dialog, misalnya sesudah minum. Penyuaraan dari glottis terbuka itu biasanya dan pada mukanya hanya mengahasilkan suara "vocal" netral, tetapi dengan pembukaan mulut lebih lebar dan gerakan lidah terjadilah variasi bunyi dan berkembanglah vokalisme primitive yang pada bulan-bulan pertama biasanya hanya berkisar antara suara [ah] dan [ah].

\section{Raban}

Di satu pihak, juga dalam perkembangan ini, alam tidak pernah meloncat, dan pergantian dari vokalisme ke fase raban berjalan dengan berangsur-angsur; dilain pihak jelas terdengar perbedaan antara bunyi berumur tiga bulan yang masih hanya bervokalisasi, dan bayi yang sudah berumur enam bulan yang sepenuhnya dalam fase raban.

Pada vokalisasi, alat ucap (dari pita suara sampai bibir) hanya sedikit bergerak, yang hanya mengakibatkan bahwa warna vokalnya agak berubah, sedangkan pada fase raban alat ucapnya ditutup atau hampir ditutup, sehungga dihasilkan konsonan hambat dan frikatif, dan jiak penutupan berlangsung lebih lama juga terbentuk nasal. Dengan demikian, disamping vokalisme primitive sekarang dihasilkan juga konsonantisme primitive.

Dalam periode raban, ucapan bunyi berlangsung dengan sepontan dan dibuat dengan sadar. Dengan demikian, halite bukan berupa bunyi yang hanya fisiologis dan kebetulan. Bunyi yang dihasulkan adalah bunyi permainan, yang tidak hanya dikeluarkan untuk menyatakan suatu kebetulan hidup vital tertentu. Bunyi-bunyi itu sudah mempunyai fungi social-raban dapat dirangsang dengan membalas berbicara, dan raban sendiri juga sudah digunakan dengan fungsi percakapan (membalas berbicara), memanggil, $\varangle$ menyatakan ketidaksabaran, dan sebaliknya. Disamping itu, dapat dihasilakn monolog raban, dalam hal ini anak melatih sendiri alat ucapnyasambil bermain-main.

Frekuensi raban, titik awalnya dan puncaknya sangat berbeda dari 340 satu anak ke satu anak lainnya; ada bayi yang mulai awal, ada yang lambat, 
ada yang banyak dan ada pula sedikit beraban. Akan tetapi, kebanyakan anak berumur enam bulan sudah beraban, dengan puncaknya sekitar umur 10-12 bulan.

\section{Penyesuaian}

Dalam fase ini pun ada pergantian perlahan-lahan. Dengan berangsurangsur suara yang tidak terdapat dalam bahasa lingkungan ditinggalkan (misalnya seperti suara [x] dan [-] dalam bahasa Indonesia) dan kumpulan suara raban diperluas dengan bunyi dan kombinasi bunyi bahasa Indonesia yang sampai saat itu belum diproduksi anak.

Ada pertumbuhan yang sangat jelas hingga saat ini: selama fase vokalisasi dan permulaan raban, alat ucap dilatih melakukan suatu aktivitas yang makin rumit, tetapi masih mempunyai kemungkinan variasi bebas, sekarang kebebasan itu makin terbatas; raban menjadi cirri khas nahasa lingkungan. Cirri-ciri pertama sudah tampak dalam bulan ke-6 - ke-7, dan sesudah ulanh tahun pertama proses penyesuaian ini selesai.

Di sini pun ada perbedaan antara anak yang satu dengan anak yang lainnya. Ada bayi yang sangat lambat dengan penyesuaian mereka, biarpun mereka beraban dengan aktif. Dugaan pertama dalam hal ini adalah pendengaran si anak kurang baik. Hal itu mungkin, tetapi sama sekali tidak selalu demikian. Namun, kelainan pendengaran sejak lahir atau sesudahnya mempunyai pengaruh negative dan menentukan keseluruhan proses pemerolehan wicara dan bahasa anak, juga pada fase penyesuaian ini.

Uraian di atas memperlihatkan bahwa ada penyesuaian wicar bayi pada sitem fonologi bahasa ibunya. Ada lagi satu penyesuaian yang bahkan lebih penting dan juga dimulai lebih awal, yaitu penyesuaian pada lagu kalimat bahasa ibu. Ibu yang sedang sibuk dengan bayinya pada umumnya memperdengarkan pola intonasi yang sangat ekspresif, yang mengungkapkan rasa sayang, menghibur, mengundang, gembira, jengkel, bertanya, kecewa, dan pendek kata seluruh kemungkinan ungkapan perasaan yang dapat disamapaikan seseorang kepada orang lain. Bahkan, juga sebelum penyesuaian bunyi, bayi kadang-kadang dengan jelas melagukan suaranya dan terutama membentuk seruan dan pertanyaan, sering dengan nada ketidak sabaran, gembira, mengasihani diri, sedikit sedih, dan sebagainya. Ucapan-ucapan mengungkapkan pengalaman pertama dengan lingkugan, perkembangan kepribadian yang paling awal dan kebutuhan berkomunikasi. 


\section{Deferensiasi Fonologi}

Di bidang bahasa anak, secara tradisional perhatian terpusat pada perkembangan fonologi. Jakobson telah meletakkan teorinya dan pendapatpendapatnya sampai sekarang masih tetap merupakan titik tolak untuk deskripsi. Lakobson juga telah meperkenalkan gagasan "semesta bahasa" (language universals). Pemerolehan system fonologi berlangsung tetap untuk semua bahasa, dan hanya deferensiasi yang terus berlangsung yang membawa anak ke system bahasa yang berlainan, begitu menurut jakobson.

Deferensiasi fonologi istimewa sekurang-kurangnya dalam satu hal dibandingkan deferensiasi di bidang struktur bahasa lainnya. Pada deferensiasi fonologi ada penyempitan, yaitu pada perubahan dari vokalisasi tidak sengaja ke vokalisasi sengaja pada fase penyesuaian.

Dalam fase raban sering muncul kombinasi suara menurut pola kv, yang merupakn dasar untuk pembentukan suku data. Dengan jalan reduplikasi, yang merupakan latihan bicara paling dasar, terjadilah pada fase ini pola kvkv (tata, mama, bobo). Hal yang menonjol adalah juga bahwa anak-anak memproduksi bunyi yang lain dan lebih banyak daripada bunyi yang sebenarnya perlu dalam bahasa sasarannya. Gejala tersebut adalah suatu semesta bahasa. Akibat gejala tersebut adalah kesulitan yang dialami oleh orang dewasa untuk memastikan latar belakang bahasa anak yang berada dalam fase raban. Dinger dan Blom menunjukkan bahwa pengenalan bahkan pada anak-anak yang berusia 1:4 tahun tetapa sulit. (Catatan: dalam penelitian bahasa anak, cara yang bisa dipakai untuk menyatakan usia anak, yaitu 1:4 yang berarti 1 tahun 4 bulan; 50 wanita Amerika dan 50 wanita Belanda ditugaskan untuk menggolongkan dua bayi Amerika dan dua bayi Belanda berumur 1:4 tahun menurut latar belakang bahasanya. Jelasnya bayi harus dikelompokkan sebagai bayi Amerika atau bayi Belanda. Ternyata hanya ada kemungkinan penenalan sebesar 68\% (termasuk kemungkinan kebetulan 50\%).

Akhir fase raban ini dapat timbul tiba-tiba dikarenakan reduksi dalam jumlah bayi. Ada gejala penyempitan yang kadang-kadang disertai dengan periode bayi yang sangat jelas. Hala yang juga merupakan gejala khas dari stadium pergantian antara periode raban dan periode kalimat saru kata adalah produksi melimpah kata-kata berpola kv yang bermakna, misalnya $m a=$ mama, $p u=p u s, p i=$ sapi, num = minum.

Menurut Jakobson, perkembangan fonem yang sebenarnya tidak terdiri atas pemerolehan fonem-fonem itu sendiri, tetapi terdiri atas 342 pemerolehan sifat fonem destingtif atau kontras-kontras atas dasar suatu 
system biner. Perkembangan tersebut dimulai dengan pemakaian $/ \mathrm{p} /$ dan a/ (direduplikasi menjadi papa; satu diantara kata-kata sejati). Penyususnan sistem fonem selanjutnya adalah pengisian kesenjangan diantara hal yang disebut Jakobson sebagai konsonan optimal, yaitu /p/ dan vocal optimal, yaitu /a/; /p/ dibentuk dibagian depan mulut dan tidak menghasilkan energy akustik, sedangkan /a/ dibentuk dibagian belakang mulut menghasilkan energy akustik dalam jumlah maksimal. Deferensiasi pertama terjadi dipihak konsonan; sementara /a/ tetap sebagai konson tunggal, di samping /p/ sekarang muncullah konsonan labial yang lain, yaitu /m/. dalam fase ini /a/ sangat penting peranannya karena dengan adanya vocal tunggal itu anak dapat membentuk suku kata ( $p a p a$ dan mama). Kemudian, timbullah di pihak konsonan deferensiasi suara lambat, disamping /p/ muncul /t/. Baru sesudahnya terjadilah deferensiasi vocal; pertama dalam bentuk /i/ di samping /a/, kemudian dalam bentuk /u/ di samping /i/. Deferensiasi suara lambat selanjutnya menghasilkan /k/ di samping /p/ dan /t/.

Menurut Jakobson, proses deferensiasi ini tetap dan universal. Anak pada mulanya hanya memproduksi suara yang terdapat dalam semua bahasa, sedangkan suara khas bahasa baru berkembang sesudahnya.

\section{Tahapan Kalimat Satu Kata}

Kalimat satu kata biasanya mulai dihasilkan anak sekitar ulang tahun pertama, tetapi bisa juga sesudah pada umur 10 bulan atau baru pada umur 14 bulan. Perbedaan itu bukan berarti merupakan indikasi kecerdasan yang lebih tinggi atau lebih rendah atau perkembangan lebih cepat atau lebih lambat.

Kata pertama baru dapat dikatakan kata pertama sejati jika tiga syarat berikut dipenuhi.

a) Kelompok bunyi yang digunakan haruslah kira-kira tetap dalam bentuknya. Seorang anak yang pada suatu saat mengucapkan mumum jika ia melihat ayahnya, pada saat lain mengucapakan ope dan pada saat yang lain lagi iih, hal itu belum menghasilakan kata. Akan tetapi, ia menghasilkan kata jika ia menggunakan binyi papa, apa, pa atau apapa untuk ayahnya dan digunakan secara bergantian; ada suatu bentuk dasar dengan variasi-variasi.

b) Syarat kedua adalah bahwa kelompok bunyi itu harus selalu menyebut hal yang sama. Anak yang menggunakan kata mam-mam untuk ayahnya, untuk sepatunya, untuk TV, belum memakai kata, tetapi masih raban. Namun, di sini pun masih ada keleluasan yang lebih besar daripada $\overline{343}$ 
bahasa orang dewasa; num-num dapat berarti minum, susu, botol susu, kaleng yang serupa dengan kaleng susu, dan hal-hal lain yang berasosiasi dengan itu.

c) Syarat ketiga adalah bahwa kata yang dipakai tidak terbatas penggunaannya hanya pada suatu situasi. Anak yang mengatakan papa dapat melakukannya bila ayahnya masuk ruangan, bila ia menyuruh ayahnya melakukan sesuatu, bila telepon bordering, bila ia menemukan sandal ayahnya, dan sebagainya.

Kalimat satu kata berbeda dari kelompok raban disebabkan sifat simbolisnya dan karena terdiri atas bunyi yang harus dikombinasi dalam urutan tertentu. Tiap bunyi merupak fonem yang berfungsi dalam keseluruhan kata yang mempunyai bentuk tetap. Hal ini membutuhkan kemampuan baru, yaitu kemampuan menata bunyi. Langkah dari kelompok raban ke kalimat satu kata sulit, bukan karena alat ucap kurang terlatih, tetapi karena bunyi-bunyi harus menghidupkan suatu dunia nyata lewat kombinasi yang unik. Kombinasi bunyi itu tidak dapat lagi dipilah dengan bebas, tetpai harus ditata terlebih dahulu.

\section{Deferensiasi Morfolofi}

Dalam tahapan-tahapan pertama perkembangan bahasa anak, anakanak tidak atau hampir tidak menggunakan kaidah morfologi. Beberapa contoh dari bahasa Ingris mungkin dapat memperjelas hal ini. Contohcontoh berikut diambil dari fase kalimat dua kata.

Adam ball (milik, tanpa's; seharusnya Adam's ball);

Two sock (jamak, tanpa - s; seharusnya twosocks);

Sun shine (persona ketiga tunggal, tanpa - s; seharusnya sunshines).

Dalam hal ini, ujaran-ujaran bahasa itu cukup interpretative. Anak memulai perkembangan bahasanya dengan satuan-satuan yang komunikatif paling penting. Kemudian, baru terjadi perstruktural lebih lanjut, juga dalam hal morfologi.

Penyelidikan deferensiasi morfologi dalam bahasa anak terutama dilakukan sehubungan dengan pembentukan jamak dan kata kerja tak beraturan (dalam bahsa fleksi). Ternyata, ada gejala yang oleh Ervin dinamakan gejala "penyamaan berlebihan" atau avergenaralization. Seperti telah dikemukakan bahwa anak-anak hanya menerapakan kaidah-kaidah 
yang mereka kuasai pada tahap tertentu dalam perkembangan bahasanya. Atas dasar kaidah-kaidah tersebut, mereka menghasilkan bahasa yang menyimpang dari bahasa orang dewasa. Sistematik dari penyimpangan itu dapat diamati terutama dibidang morfologi. Timbulnya bentuk-brntuk dalam bahasa anak seperti writed dan memakan menunjukkan adanya penyamaan berlebihan dari kaidah-kaidah untuk pembentukan kata kerja, baika dalam bahasa Ingris maupun dalam bahasa Indonesia. Anak-anak mulai dengan kaidah yang palin umum dan baru kemudia belajar kekecualiankekecualiannya. Anak menghasilkan bentukan seperti writed dan memakan karena pada saat itu bentuk-bentuk tersebut dapat diterima di dalam system kaidahnya.

Ervin menunjukkan adanya kesejajaran dalam perkembangan pembentukan jamak dan kata kerja. Hal itu dapat dijelaskan sebagai berikut.

a) Pada tahapan pertama anak-anak meniru bentuk yang benar (came, mice, duduk, sembunyi).

b) Pada tahapah kedua terjadi penyamaan berlebihan (camed, mouses, menduduk, bersembunyi).

c) Pada tahapan ketiga, anak lalu belajar bahwa ada kekecualian dari kaidah-kaidah pembentukan jamak dan kata kerja (came, mice, duduk, bersembunyi) (Widjajanti W.Dharmowijiyo, Nyoman Suparwa, 2009: 6878).

Jadi, apabila dilihat dari bagaimana proses terjadinya berbahasa dalam arti berkomunikasi, Chaer menjelaskan seperti berikut:

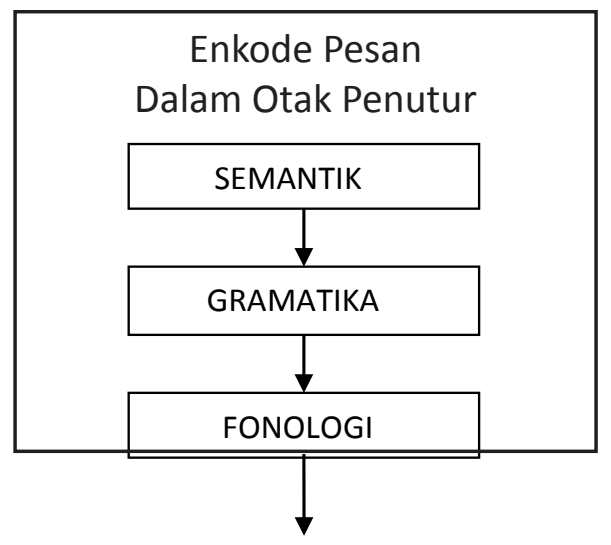




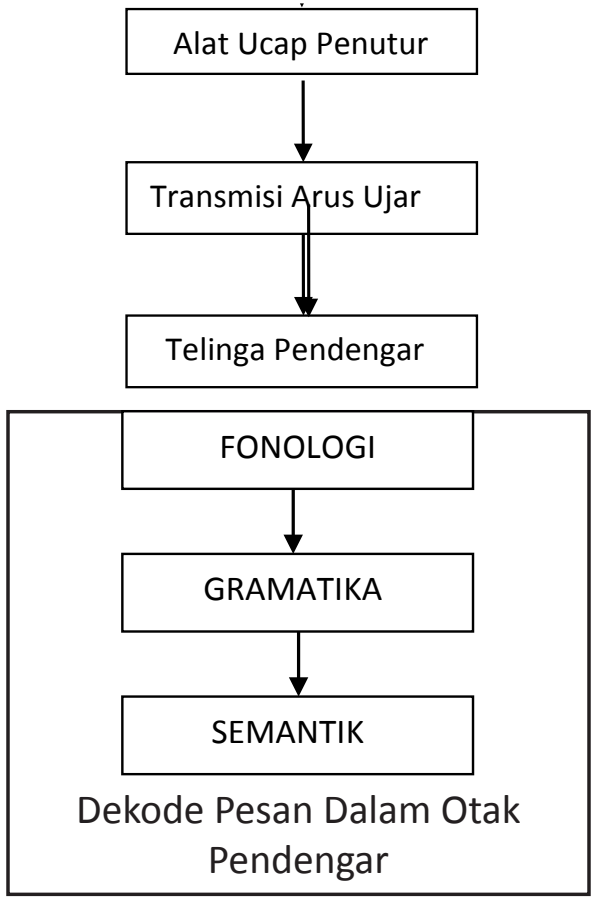

Dalam uraian di atas, berbahasa dijelaskan hanya sebagai proses searah. Artinya, dari seorang pembicara kepada seorang pendengar. Padahal di dalam berkomunikasi yang sebenarnya proses tersebut bisa terjadi bolak-balik atau dua arah. Maksudnya, pada awalnya, misalnya, si A menjadi pembicara, sedangkan si B menjadi pendengar. Kemudian proses ini berganti, si B menjadi pembicara dan si A menjadi pendengar. Proses inipun terjadi dengan cepat, tidak "selambat" seperti penjelasan di atas, selain iu dalam berbahasa yang sebenarnya konteks situasi dan unsur para linguistik turut membangun makna yang akan dipahami oleh partisipan dalam tindak atau perilaku berbahasa itu (Abdul Chaer, 2002:45-48).

\section{Simpulan}

Berdasarkan pada paparan di atas, kiranya pembaca utamanya tenaga pendidik yang berkecimpung dalam dunia pendidikan usia dini dapat mengerti bahwasannya bahasa yang digunakan untuk menyampaikan pesan moral, pendidikan secara umum harus dapat mempertimbangkan bagaimana kemampuan bahasa mereka, karena bahasa mereka mencerminkan bagaimana kadar intelektual, kadar psikis dan juga perkembangannya mengalami peningkatan atau hambatan. Guru kiranya dapat peka dengan bahasa mareka dan juga bahasa yang akan digunakan untuk berkomunikasi. 


\section{DAFTAR PUSTAKA}

Abdul Chaer, Psikolinguistik Kajian Teoritik, Jakarta: Rineka Cipta, 2003.

Abdul Chaer, Linguistik Umum, (Jakarta: Rineka Cipta, 2003)

Imam Asrori, Sintaksis Bahasa Arab, Malang, Misykat, 2004.

J.W.M. Verhaar, Asas-asas Linguistik Umum, Gadjah Mada University Press, Jogjakarta, 2012.

Sumarsono, Sosiolinguistik, Jogjakarta, Pustaka Pelajar, 2007.

Soenjono Drdjowidjojo, Psikolinguistik, Yayasan Obor Indonesia, Jakarta, 2005.

Widjajanti W.Dharmowijiyo, Nyoman Suparwa, Psikolinguistik, Cet-1, Dempasar, Udayana University Press, 2009. 